\title{
Journal of Dental Research
}

http://jdr.sagepub.com/

\section{Distribution and Excretion of BisGMA in Guinea Pigs}

F.X. Reichl, M. Seiss, N. Kleinsasser, K. Kehe, K.H. Kunzelmann, P. Thomas, W. Spahl and R. Hickel J DENT RES 2008 87: 378

DOI: $10.1177 / 154405910808700401$

The online version of this article can be found at:

http://jdr.sagepub.com/content/87/4/378

\author{
Published by: \\ (SAGE \\ http://www.sagepublications.com \\ On behalf of: \\ International and American Associations for Dental Research
}

Additional services and information for Journal of Dental Research can be found at:

Email Alerts: http://jdr.sagepub.com/cgi/alerts

Subscriptions: http://jdr.sagepub.com/subscriptions

Reprints: http://www.sagepub.com/journalsReprints.nav

Permissions: http://www.sagepub.com/journalsPermissions.nav

>> Version of Record - Apr 1, 2008

What is This? 
F.X. Reichl1*,2, M. Seiss ${ }^{2}$, N. Kleinsasser ${ }^{3}$, K. Kehe ${ }^{4}$, K.H. Kunzelmann ${ }^{1}$, P. Thomas ${ }^{5}$, W. Spahl' 6 , and R. Hickel ${ }^{2}$

${ }^{1}$ Department of Operative/Restorative Dentistry, Periodontology and Pedodontics, Ludwig-MaximiliansUniversity of Munich, Goethestr. 70, 80336 Munich, Germany; ${ }^{2}$ Walther-Straub-Institute of Pharmacology and Toxicology, Ludwig-Maximilians-University of Munich, Nussbaumstr. 26, 80336 Munich, Germany; ${ }^{3}$ Department of Otolaryngology-Head and Neck Surgery, University of Wuerzburg, Josef-Schneider-Str. 11, 97080 Wuerzburg, Germany; ${ }^{4}$ Institute of Pharmacology and Toxicology, Sanitätsakademie der Bundeswehr, Neuherbergstr. 11, 80937 Munich, Germany; ${ }^{5}$ Department of Dermatology und Allergology, Ludwig-Maximilians-University of Munich, Frauenlobstrasse 9-11, 80337 Munich, Germany; and ${ }^{6}$ Institute of Organic Chemistry, Ludwig-MaximiliansUniversity of Munich, Marchioninistr. 15, 81377 Munich, Germany; *corresponding author, reichl@lmu.de

J Dent Res 87(4):378-380, 2008

\section{ABSTRACT}

Bisphenol-A-glycidyldimethacrylate (BisGMA) is used in many resin-based dental materials. It was shown in vitro that BisGMA was released into the adjacent biophase from such materials during the first days after placement. In this study, the uptake, distribution, and excretion of $\left[{ }^{14} \mathrm{C}\right]$ BisGMA applied via gastric and intravenous administration (at dose levels well above those encountered in dental care) were examined in vivo in guinea pigs to test the hypothesis that BisGMA reaches cytotoxic levels in mammalian tissues. $\left[{ }^{14} \mathrm{C}\right]$ BisGMA was taken up rapidly from the stomach and intestine after gastric administration and was widely distributed in the body following administration by each route. Most $\left[{ }^{14} \mathrm{C}\right]$ was excreted within one day as ${ }^{14} \mathrm{CO}_{2}$. The peak equivalent BisGMA levels in guinea pig tissues examined were at least 1000-fold less than known toxic levels. The peak urine level in guinea pigs that received well in excess of the body-weightadjusted dose expected in humans was also below known toxic levels. The study therefore did not support the hypothesis.

KEY WORDS: BisGMA, metabolism, excretion, organs, guinea pig.

Received August 8, 2007; Last revision November 29, 2007; Accepted December 23, 2007

A supplemental appendix to this article is published electronically only at http://jdr.iadrjournals.org/cgi/ content/full/87/4/378/DC1.

\section{Distribution and Excretion of BisGMA in Guinea Pigs}

\section{INTRODUCTION}

D esin-containing materials are used routinely in dental practice as direct filling materials, fissure sealing agents, bonding resins, and resin cements. Among the components of most bonding and restorative resins are: (1) a primary resin, usually bisphenol-A-glycidyldimethacrylate (BisGMA); and (2) triethyleneglycoldimethacrylate (TEGDMA), which is included to compensate for the high viscosity of the primary resin. Resin composites contain BisGMA in amounts varying from 5-9 wt\% (Munksgaard et al., 2000), while fissure sealants contain BisGMA in the range 10-50\% (Komurcuoglu et al., 2005).

Direct evidence of BisGMA release from composite resins and fissure sealants into the biophase was provided previously (Tanaka et al., 1991; Spahl et al., 1998; Nalcaci et al., 2006). Released dental material components can be expected to enter the body by 2 different routes after resin placement, via the saliva and gastrointestinal tract, plus (if the material is placed on dentin) via the dentin and pulp (Hume and Gerzina, 1996).

To test the hypothesis that BisGMA reaches cytotoxic levels in body tissues, and to develop an understanding of the whole-body kinetics of BisGMA, we measured the uptake, distribution, and clearance of $\left[{ }^{14} \mathrm{C}\right]$ BisGMA administered by gastric tube and by intravenous injection in guinea pigs.

\section{MATERIALS \& METHODS}

$\left[{ }^{14} \mathrm{C}\right]$ BisGMA was purchased from Perkin Elmer (Boston, MA, USA), dissolved in dichloromethane, and stored at $-20^{\circ} \mathrm{C}$. Unlabeled BisGMA was obtained from Degussa (Frankfurt, Germany).

\section{In situ Experiments}

Guinea pigs were randomized and allotted to 3 groups of 4 animals each. The animals were anesthetized with urethane $(1 \mathrm{mg} / \mathrm{kg}, 4 \mathrm{~mL} / \mathrm{kg}$; dissolved in $0.9 \%$ $\mathrm{NaCl}$ solution). The ductus cysticus was ligated, and a cannula was placed in the bile duct, as described in previous experiments (Reichl et al., 2001). A $1 \mathrm{~mL} / \mathrm{kg}$ quantity of BisGMA, dissolved in DMSO (final DMSO concentration, 1\%), was injected via the jugular vein $[0.02 \mu \mathrm{mol} / \mathrm{kg}$ body weight (bw), labeled with a tracer dose of $\left[{ }^{14} \mathrm{C}\right] \mathrm{BisGMA}, 0.3 \mathrm{kBq} / \mathrm{g}$ bw] (group 1). Control animals (groups 2 and 3 ) received either $0.9 \% \mathrm{NaCl}$ solution or DMSO (final DMSO concentration, $1 \%$ in $0.9 \% \mathrm{NaCl}$ solution), each without BisGMA. Blood was withdrawn from the carotid artery. Samples of the bile $(0.4 \mathrm{~mL})$ and blood $(0.2 \mathrm{~mL})$ were taken every $10 \mathrm{~min}$. The experimental period was $60 \mathrm{~min}$. The organs and their contents were immediately removed and their $\left[{ }^{14} \mathrm{C}\right]$-radioactivity measured.

\section{In vivo Experiments}

Adult male guinea pigs (Dunkin-Hartley Pirbright white strain, $400 \mathrm{~g}$ ), were fed a standard diet and water ad libitum. Twelve guinea pigs were allotted to 3 groups of 4 animals each. Each animal was put into a separate metabolic cage 3 days before and food was removed $12 \mathrm{hrs}$ before the experiment. Each animal 


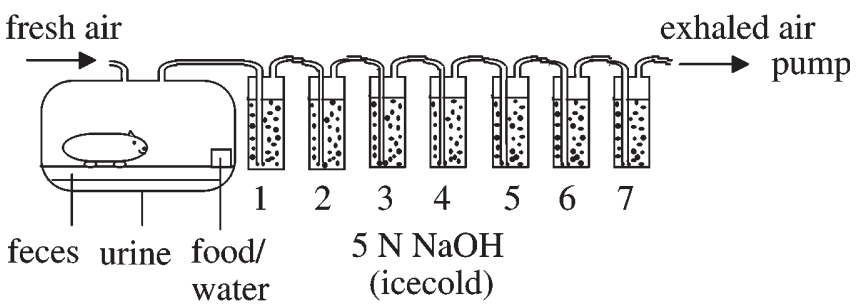

Figure. Metabolic cage with controlled air flow for capturing $\left[{ }^{14} \mathrm{C}\right]-$ carbon dioxide. Exhaled carbon dioxide was captured by pumping the exhaled air through bottles 1-7, each filled with ice-cold $5 \mathrm{~N} \mathrm{NaOH}$.

received BisGMA $(0.02 \mu \mathrm{mol} / \mathrm{kg}$ bw, dissolved $1 \%$ DMSO solution, labeled with a tracer dose of $\left[{ }^{14} \mathrm{C}\right] \mathrm{Bis} G M A, 0.3 \mathrm{kBq} / \mathrm{g}$ bw) via gastric tube (group 4). Control animals (groups 5 and 6) received either $0.9 \% \mathrm{NaCl}$ solution or DMSO (final DMSO concentration, $1 \%$ ), each without BisGMA. The volume for the application through the gastric tube was $4 \mathrm{~mL} / \mathrm{kg}$. Feces and urine were collected at $1,2,4,6,8,12$, and $24 \mathrm{hrs}$ after $\left[{ }^{14} \mathrm{C}\right]$ BisGMA administration, and the $\left[{ }^{14} \mathrm{C}\right]$-radioactivity was measured as described below. Twenty-four hrs after the beginning of the experiment, the animals were killed in ether. The organs and their contents were immediately removed and their $\left[{ }^{14} \mathrm{C}\right]$-radioactivity measured. Details of organ treatment and the method of determination of radioactivity are in the APPENDIX. Data are presented as means \pm SEM. Statistical significance of the differences between the experimental groups was determined by the Bonferroni-Holm $t$ test (Sheskin, 2007).

A second set of 12 guinea pigs was treated as described above, with the addition that each animal was kept in a closed chamber with controlled air flow. The exhaled air was captured during the 24-hour experimental period by flowing through 7 bottles, 1 behind the other, filled with $250 \mathrm{~mL}$ ice-cold $5 \mathrm{~N} \mathrm{NaOH}$ (see Fig.). $\left[{ }^{14} \mathrm{C}\right]$-carbon dioxide was captured as $\left[{ }^{14} \mathrm{C}\right]-\mathrm{Na}_{2} \mathrm{CO}_{3}$ and the total $\left[{ }^{14} \mathrm{C}\right]$ activity determined. Urine and feces were collected at $24 \mathrm{hrs}$ after the beginning of the experiment, and the animals were killed and organs taken for analysis as described for the first in vivo experimental group.

\section{Declaration}

These experiments complied with the current laws of Germany. The animal experiments were approved by the Regierung von Oberbayern, permission no. 211-2531-66/94.

The accession number for ${ }^{14} \mathrm{C}$ compounds is: 4/4-8816.35214783, Bayerisches Landesamt für Umweltschutz, Augsburg, Germany.

\section{Guinea Pig Organs}

Organs taken and tested were: liver, kidney, blood, skin, brain, heart, spleen, lung, muscle, testes, eyes, bone, nerve tissue, spinal cord, wall of stomach, content of stomach, wall of ileum + jejunum, content of ileum + jejunum, wall of colon, content of colon, wall of caecum, content of caecum, wall of gall bladder, and fat tissue. Organs were immediately washed with $2 \times 10 \mathrm{~mL}$ distilled $\mathrm{H}_{2} \mathrm{O}$, the wash-water was saved, and then the tissues were weighed and homogenized.

\section{Determination of Radioactivity, Guinea Pig Experiments}

Tissues were dissolved in tetraethylammoniumhydroxide (TEAH) $(20 \%)$ in aqueous solution with Omni-Szintisol ${ }^{\circledR}$ (both from
Table 1. $\left[{ }^{14} \mathrm{C}\right]$ Recovery in Guinea Pigs in the Bile and Blood, as well as Summed [ ${ }^{14} \mathrm{C}$ ] Distribution in Organs $1 \mathrm{hr}$ after Intravenous $\left[{ }^{14} \mathrm{C}\right]$ BisGMA Injection $(\mathrm{n}=4$; mean $\pm \mathrm{SEM})$

$$
\begin{gathered}
{\left[{ }^{14} \mathrm{C}\right] \text { Activity }} \\
\text { (\% of the }\left[{ }^{14} \mathrm{C}\right] \mathrm{Bis} \mathrm{B} M A \text { dose administered) } \\
\text { Intravenous Injection }
\end{gathered}
$$

\begin{tabular}{lrl} 
& Mean & SEM \\
\hline Bile & 12.0 & 2.1 \\
Blood & 1.1 & 0.1 \\
Organ wash water & 0.8 & 0.2 \\
Z organs & 49.6 & 5.5 \\
\hline
\end{tabular}

Table 2. $\left[{ }^{14} \mathrm{C}\right]$ Excretion in Guinea Pigs via the Urine, Feces, and Carbon Dioxide as well as Summed $\left[{ }^{14} \mathrm{C}\right.$ ] Distribution in Organs $24 \mathrm{hrs}$

\begin{tabular}{|c|c|c|}
\hline & \multicolumn{2}{|c|}{$\begin{array}{c}{\left[{ }^{14} \mathrm{C}\right] \text { Activity }} \\
\text { (\% of the }\left[{ }^{14} \mathrm{C}\right] \mathrm{Bis} \mathrm{GMA} \text { dose administered) } \\
\text { Application with the Gastric Tube }\end{array}$} \\
\hline & Mean & SEM \\
\hline Urine & 7.3 & 1.1 \\
\hline Feces & 5.0 & 0.8 \\
\hline Exhaled ${ }^{14} \mathrm{CO}_{2}$ & 65.3 & 2.3 \\
\hline Organ wash water & 1.2 & 0.2 \\
\hline$\sum$ organs & 5.8 & 0.9 \\
\hline Total $\left[{ }^{14} \mathrm{C}\right]$ recovery & 84.6 & 2.8 \\
\hline
\end{tabular}
after $\left[{ }^{14} \mathrm{C}\right] \mathrm{Bis} G M A$ Administration with a Gastric Tube ( $\mathrm{n}=4$; mean \pm SEM)

Merck, Darmstadt, Germany). Radioactivity was determined by the method described by Strugala (1984), with a liquid scintillation counter (2500 TR, Canberra-Packard, Dreieich, Germany).

\section{RESULTS}

\section{$\left[{ }^{14} \mathrm{C}\right]$ Recovery from Guinea Pigs after $1 \mathrm{Hr}$}

During the first hr after $\left[{ }^{14} \mathrm{C}\right]$ BisGMA intravenous injection, about $12 \%$ of the $\left[{ }^{14} \mathrm{C}\right]$ was excreted via the bile, and about $50 \%$ remained in the tissues at $1 \mathrm{hr}$, the time the guinea pigs were killed (Table 1$).\left[{ }^{14} \mathrm{C}\right]$ activity was rapidly removed from the blood (Table 1). Additional data on $\left[{ }^{14} \mathrm{C}\right]$ distribution in the bile and blood and $\left[{ }^{14} \mathrm{C}\right]$ activity in various organs are included in the APPENDIX.

\section{$\left[{ }^{14} \mathrm{C}\right]$ Recovery from Guinea Pigs after $24 \mathrm{Hrs}$}

During the first $24 \mathrm{hrs}$ after $\left[{ }^{14} \mathrm{C}\right]$ BisGMA oral administration, guinea pigs exhaled ${ }^{14} \mathrm{CO}_{2}$ equivalent to about $65 \%$ of the $\left[{ }^{14} \mathrm{C}\right]$ BisGMA dose administered (Table 2). About $7 \%$ of the $\left[{ }^{14} \mathrm{C}\right]$ was excreted via urine, and about $6 \%$ remained in the tissues at $24 \mathrm{hrs}$, the time the guinea pigs were killed (Table 2). The total $\left[{ }^{14} \mathrm{C}\right]$ recovery was about $85 \%$ of the $\left[{ }^{14} \mathrm{C}\right]$ BisGMA dose administered (Table 2). Additional data on fecal and urinary volumes, $\left[{ }^{14} \mathrm{C}\right]$ excretion, and $\left[{ }^{14} \mathrm{C}\right]$ activity in various organs are included in the APPENDIX. 


\section{DISCUSSION}

The administered dose levels were chosen to exceed substantially the body-weight-adjusted dose levels relative to humans for BisGMA released from large composite resin restorations. For the guinea pig experiments, we used the data of Munksgaard et al. (2000), who measured extracted quantities from polymerized composites eluted for 7 days with water. The values for various composite components eluted in these chemical experiments ranged from 0.03 to $0.07 \mathrm{wt} \%$ in water. The highest eluted BisGMA level into water shown by Munksgaard et al. (2000) was from the commercial composite Z100 ${ }^{\circledR}$ (3M ESPE, Seefeld, Germany), which provided about $1.5 \mu \mathrm{mol}$ BisGMA from $16 \mathrm{~g}$ composite. Assuming the worst case, that all restorations in all teeth are replaced by Z100 (32 teeth; about 0.5 grams per tooth/filling = about $16 \mathrm{~g} \mathrm{Z100),} \mathrm{a}$ dose level equivalent to the total amount released from this material was used and adjusted by proportion with the body weight of the average human $(1.5 \mu \mathrm{mol}$ BisGMA $/ 70 \mathrm{~kg} \mathrm{bw}=$ $0.02 \mu \mathrm{mol} / \mathrm{kg} \mathrm{bw})$.

Analysis of our data showed that uptake of $\left[{ }^{14} \mathrm{C}\right] \mathrm{BisGMA}$ from the stomach and intestine of guinea pigs was rapid and essentially complete, and that distribution of $\left[{ }^{14} \mathrm{C}\right] \mathrm{BisGMA}$ and/or its metabolites throughout the body with these routes of administration was broad. More than $65 \%$ of the administered $\left[{ }^{14} \mathrm{C}\right]$ was excreted via the lungs as ${ }^{14} \mathrm{CO}_{2}$ in guinea pigs, while some $7 \%$ of the administered $\left[{ }^{14} \mathrm{C}\right]$ appeared in the urine. Most of the $\left[{ }^{14} \mathrm{C}\right]$ label was cleared from the body one day following gastric administration.

The cumulative biliary $\left[{ }^{14} \mathrm{C}\right]$ excretion was about 2 times higher after $60 \mathrm{~min}$ than the cumulative fecal $\left[{ }^{14} \mathrm{C}\right]$ excretion after $24 \mathrm{hrs}$. Therefore, enterohepatic recycling of $\left[{ }^{14} \mathrm{C}\right]$ BisGMA and/or $\left[{ }^{14} \mathrm{C}\right]$ BisGMA metabolite(s) cannot be excluded. Enterohepatic recycling and similar biological clearances have also been described for HEMA and TEGDMA in guinea pigs (Reichl et al., 2001, 2002). Analysis of the present data indicates the existence of similar mechanisms for uptake and biliary excretion for HEMA, TEGDMA, and BisGMA.

We did not determine where, in the organism, BisGMA was metabolized to carbon dioxide. However, the moderately elevated levels in the lung relative to other tissues after intravenous or oral administration suggest metabolic conversion in that tissue. Furthermore, metabolism of BisGMA and formation of $\mathrm{CO}_{2}$ from BisGMA appear to be independent of these routes of administration, i.e., metabolism of BisGMA in the stomach and/or in the intestine is very unlikely. Further discussion about possible metabolic pathways and distribution and clearance following intravenous and oral administration is included in the APPENDIX.

Despite the fact that the body-weight-adjusted dose of BisGMA administered was more than 20 times higher than that which would be encountered by a human, the highest levels of BisGMA observed in tissue samples taken from guinea pigs, 1.5 nano $\mathrm{M}$ in the lung, $1 \mathrm{hr}$ after intraveneous injection are approximately 1000-fold less than the known toxic level for BisGMA (Kostoryz et al., 2003; Schwengberg et al., 2005; Reichl et al., 2006; Schweikl et al., 2006).

Similarly, with a dose well in excess of the weightadjusted, expected equivalent in humans, the highest $\left[{ }^{14} \mathrm{C}\right]$ concentration in the spontaneous urine in guinea pigs was found $4 \mathrm{hrs}$ after the oral $\left[{ }^{14} \mathrm{C}\right]$ application $(1.2 \%$ in $1.4 \mathrm{~mL})$. Peak levels in blood and kidney tissue occurred much earlier than this, which is consistent with the known time dynamics of urine production and the variable (but expected) delay before urine release. Calculated from this $\left[{ }^{14} \mathrm{C}\right]$ peak concentration in the urine at the dose administered, a peak BisGMA concentration in the spontaneous urine can be estimated at about $0.2 \mathrm{nmol} / \mathrm{L}$. This concentration is at least $1 / 500,000$ th of the level that decreased the cell survival ratio in kidney cells (Hikage et al., 1999). It is therefore unlikely that BisGMA released from restorative materials could have any systemic, toxic effects. However, it is noted that only general cytotoxic effects were investigated in association with BisGMA, and there may be many as-yet-uninvestigated toxic effects generated in various cells by this substance.

The possibility of allergic responses in patients and in dental workers is discussed in the APPENDIX.

\section{ACKNOWLEDGMENTS}

This work was supported by the Deutsche Forschungsgemeinschaft RE 633/2-1/4. The authors acknowledge the technical assistance of Stefan Schulz.

\section{REFERENCES}

Hikage S, Sato A, Suzuki S, Cox CF, Sakaguchi K (1999). Cytotoxicity of dental resin monomers in the presence of S9 mix enzymes. Dent Mater $J 18: 76-86$

Hume WR, Gerzina TM (1996). Bioavailability of components of resinbased materials which are applied to teeth. Crit Rev Oral Biol Med 7:172-179.

Komurcuoglu E, Olmez S, Vural N (2005). Evaluation of residual monomer elimination methods in three different fissure sealants in vitro. $J$ Oral Rehabil 32:116-121.

Kostoryz EL, Eick JD, Glaros AG, Judy BM, Welshons WV, Burmaster S, et al. (2003). Biocompatibility of hydroxylated metabolites of BISGMA and BFDGE. $J$ Dent Res 82:367-371.

Munksgaard EC, Peutzfeld A, Asmussen E (2000). Elution of TEGDMA and BisGMA from a resin and a resin composite cured with halogen or plasma light. Eur J Oral Sci 108:341-345.

Nalcaci A, Ulusoy N, Atakol O (2006). Time-based elution of TEGDMA and BisGMA from resin composite cured with LED, QTH and highintensity QTH lights. Oper Dent 31:197-203.

Reichl FX, Durner J, Kunzelmann KH, Hickel R, Spahl W, Hume WR, et al. (2001). Biological clearance of TEGDMA in guinea pigs. Arch Toxicol 75:22-27.

Reichl FX, Durner J, Kehe K, Manhart J, Folwaczny M, Kleinsasser N, et al. (2002). Toxicokinetic of HEMA in guinea pigs. J Dent 30:353-358.

Reichl FX, Simon S, Esters M, Seiss M, Kehe K, Kleinsasser N, et al. (2006). Cytotoxicity of dental composite (co)monomers and the amalgam component $\mathrm{Hg}^{2+}$ in human gingival fibroblasts. Arch Toxicol $80: 465-472$.

Schweikl H, Spagnuolo G, Schmalz G (2006). Genetic and cellular toxicology of dental resin monomers. J Dent Res 85:870-877.

Schwengberg S, Bohlen H, Kleinsasser N, Kehe K, Seiss M, Walther UI, et al. (2005). In vitro embryotoxicity assessment with dental restorative materials. $J$ Dent 33:49-55.

Sheskin DJ (2007). The handbook of parametric and nonparametric statistical procedures. 4th ed. New York: Chapman and Hall/CRC.

Spahl W, Budzikiewicz H, Geurtsen W (1998). Determination of leachable components from four commercial dental composites by gas and liquid chromatography/mass spectrometry. J Dent 26:137-145.

Tanaka K, Taira M, Shintani H, Wakasa K, Yamaki M (1991). Residual monomers (TEGDMA and Bis-GMA) of a set visible-light-cured dental composite resin when immersed in water. J Oral Rehabil 18:353-362. 